\title{
Strategic Planning and Organisational Effectiveness in Jordanian Hotels
}

\author{
Jehad Aldehayyat ${ }^{1} \&$ Adel Al Khattab ${ }^{1}$ \\ ${ }^{1}$ Department of Business Administration, College of Business Administration and Economics, Al-Hussein Bin \\ Talal University \\ Correspondence: Jehad Aldehayyat, Department of Business Administration, College of Business \\ Administration and Economics, Al-Hussein Bin Talal University, P. O. Box 149, Ma'an71110, Jordan. Tel: \\ 962-3-2135-516. E-mail: j.aldehayyat@yahoo.co.uk
}

Received: June 10, 2012

Accepted: June 18, 2012

Online Published: December 4, 2012

doi:10.5539/ijbm.v8n1p11

URL: http://dx.doi.org/10.5539/ijbm.v8n1p11

\begin{abstract}
The tourism sector in Jordan is the second largest private sector employer and the second highest producer of foreign exchange. This sector, however, has been affected by many external factors in the Middle East, such as wars, turmoil and, most recently, the Arab Spring. Given the changing environment in which these hotels are doing business, they require a high ability for adaptation in order to grow and compete. Despite this, little research has been undertaken in this area. This research, therefore, aims to identify and examine the characteristics of strategic planning systems in Jordanian hotels and their relationship with organizational effectiveness.

In order to achieve this aim, a questionnaire is developed after reviewing the literature related to strategic planning and its effectiveness in both developed and emerging markets. The empirical research is undertaken via a survey of all four- and five-star hotels operating around Jordan's most popular tourist attractions: Amman, the Dead Sea, Petra and Aqaba. A total of 138 questionnaires were handed to the entire target population of 46 hotels. This questionnaire yielded an $80.4 \%$ per cent response rate.

The main findings of this research are: the mean time horizon for strategic planning is 5.4 years; top management and boards of directors have less participation in strategic planning processes than outside consultants; internal scanning is used less frequently than external scanning; some important strategy analysis tools are used less frequently than traditional ones; and the areas of research and development and technology are rarely covered. However, strategic planning is found to be positively and significantly related to organisational effectiveness.
\end{abstract}

Keywords: strategic planning, organisational effectiveness, Jordan, hotels, emerging market

\section{Introduction}

In today's global economy, tourism is considered the world's largest and most important service sector and its most dynamic industry (Stancious, Teodorescu, Pargaru, Vladol \& Balesc, 2011). This industry has been growing around the world and has become a major source of income and employment for many countries. The industry, as stated by the World Tourism Organization [UNWTO] (2009), benefits local economic stability by increasing foreign exchange earnings, creating emplacement and investment opportunities, increasing government revenues, developing a country's image and supporting all sectors of its economy, as well as local communities. Nowadays, tourism, as suggested by Ardahaey (2011), is considered a major economic contributor in many countries worldwide, adding value for foreign exchange but also support for export industries and support and protection for countries' environmental, social, cultural and historic resources.

Governments, therefore, are becoming increasingly aware of the positive benefits of tourism in terms of generating foreign exchange revenues, attracting foreign investment and creating employment opportunities, not to mention its spillover benefits to other segments of the economy. As global competition heightens, developing countries, as reported by $\mathrm{ABC}$ Investment (2011), are working hard to promote tourism as a driver of sustainable economic development. In 2010, the travel and tourism industry generated $9.3 \%$ of the global GDP and assured around 236 million jobs (World Travel and Tourism Council, 2011). According to UNWTO (2010), in the year 2012. UNWTO (2010) expects the tourism sector to provide 296 million jobs by 2019. As shown in 
Table 1, UNWTO (2009) predicts a growth rate of 6.7\% in visitors to the Middle East between 2010 and 2020. This rate is the second highest among Europe, East Asia, the Americas, Africa and south Asia.

Table 1. International tourist arrivals by region-percentage growth (Global average 4.5\%)

\begin{tabular}{cc}
\hline Region & Growth rate \\
\hline Middle East & 6.7 \\
Europe & 3.1 \\
East Asia/Pacific & 7.4 \\
Americas & 4.0 \\
Africa & 5.1 \\
South Asia & 5.8 \\
\hline
\end{tabular}

\section{Literature Review}

\subsection{Tourism in Jordan}

International tourism continues to develop worldwide; the Middle East, as reported by UNWTO (2010), is still among the fastest growing regions. In Jordan, as shown in Table 2, UNWTO (2010) reported a 3.789\% growth rate in visitors in 2009. Tourism, furthermore, continues to be a long-term driver of economic growth, accounting for the largest slice of GDP in the country's productive economy (Ministry of Tourism and Antiques, 2011). As reported by the Ministry of Tourism and Antiques (2011), tourism is Jordan's second largest private sector employer and its second highest producer of foreign exchange. Jordan experienced a steady increase in tourism during the first decade of the 21st century. The Ministry of Tourism and Antiques (2011) reported more than eight million tourism arrivals in 2010, of which 4.55 million were overnight visitors - this equates to a 20.3\% increase in overnight visitors from 2009. Tourism expenditure reached more than USD 3.412 billion, which contributed about $12.4 \%$ to the national GDP. In 2010, direct employment reached 41,900; tourism is estimated to support several hundred thousand full time-equivalent jobs economy-wide when the full multiplier impact is accounted for.

Table 2. International tourist arrivals by region (Middle East)-percentage growth

\begin{tabular}{cccc}
\hline \multirow{2}{*}{ Major Destination } & \multicolumn{3}{c}{$\mathbf{1 0 0 0}$} \\
\cline { 2 - 4 } & $\mathbf{2 0 0 7}$ & $\mathbf{2 0 0 8}$ & $\mathbf{2 0 0 9}$ \\
\hline Egypt & 10,610 & 12,296 & 11,914 \\
Jordan & 3,430 & 3,729 & 3,789 \\
Lebanon & 1,017 & 1,333 & 1,851 \\
Palestine & 264 & 387 & 396 \\
Qatar & 964 & 1,405 & 1,659 \\
Saudi Arabia & 11,531 & 14,757 & 10,896 \\
Syria & 4,158 & 5,430 & 6,092 \\
Yemen & 379 & 404 & 434 \\
Oman & 1,124 & 1,273 & $\ldots$ \\
Bahrain & 4,935 & $\ldots$ & $\ldots$ \\
\hline
\end{tabular}

Source: World Tourism Organization (UNWTO), 2010

Thus, tourism, as suggested by Majcher-Teleon and Ben Slimène (2009), is considered one of the most dynamic economic sectors in Jordan, and has been identified by the government as one of the priority sectors for development. To support this, a new Tourism Law has recently been developed. This law aims to promote public-private partnerships, facilitate increased investments and help to improve the standards and quality of 
products and services. The law supports a number of changes, including the development of a clear legislative framework to delineate and monitor tourism resources in the country; enhance the role of Ministry of Tourism and Antiques in formulating and institutionalizing strategic planning for development, seeking to lead the sector and expand and protect the pool of human resources.

The law also calls for enhancement and activation of the role of the private sector in the management and growth of resources and the establishment of a modern system to regulate the main professions in attaining best practice standards in services (Majcher-Teleon \& Ben Slimène, 2009, p. 19). Moreover, the United States Agency for International Development (USAID), as reported by Siyaha (2012), has established the Jordan Tourism Development Project (Siyaha) as a public-private partnership with funding of USD 17 million. The project, as stated by ABC Investment (2009), aims at facilitating the implementation of the National Tourism Strategy: supporting the private sector in developing tourism products and services, and working hand in hand with the Jordanian government to develop the tourism industry in the country and expand employment.

The tourism industry in Jordan, however, has been affected by many external factors in the Middle East, such as a number of wars and, more recently, the Arab Spring. Jordanian hotels therefore, require a high ability to adapt to a changing environment in order to grow and compete with other tourism organisations both inside and outside Jordan (Aldehayyat, 2011). Chon and Olsen (1990) argued that in order for tourism organisations to make better estimates of the future and thus make sound management decisions, they should formally incorporate the strategic planning process into the structure of their operations.

Strategic planning, as defined by Ocasio \& Joseph (2008), is a form of planning practice intended to formulate strategy. Strategic planning is, therefore, a particular form of strategising, one that involves the application of planning practice. Consequently, the concept - as suggested by Ocasio \& Joseph (2008) - is a formalized procedure seeking to produce a particular outcome or result in the form of an integrated system of decisions. Rigby \& Bilodeau (2007) added that strategic planning is the most widely used tool among both small and large organisations, aiming to provide direction and ensuring that the appropriate resources are available at a suitable place and time for the pursuit of objectives. Indeed, in a study of senior executives of organisations in 15 countries around the world, Rigby (2001) found that $81 \%$ of the organisations conducted strategic planning. Moreover, senior executives reported a higher level of satisfaction with strategic planning than with most other management tools.

A growing body of the related literature has investigated strategic planning in manufacturing and service industries (e.g. Brews \& Purohit, 2007; Glaister, Dincer, Tatoglu, \& Demirbag, 2009). Hospitality and strategy scholars (e.g. Reichel, 1983; Schaffer, 1986; Phillips \& Moutinho, 1999; Okumus, 2002; Harrington, 2004) advocate strategic planning as an important tool to enhance business performance in tourism organizations. Despite this, and as suggested by Phillips and Moutinho (1999), there has been little work on strategic planning and its relationship with organisational effectiveness particularly in tourism organisations. In this essence, Ghobadian, O'Regan, Thomas, \& Liu (2008) argued that examination of the impact of strategic planning on corporate performance is one of the enduring elements of process research. Ghobadian et al. (2008) note that such research effort has slowed down over the past decade, despite the use of strategic planning having increased among organisations.

In emerging markets, particularly in Jordan, a few studies have reported on the strategic planning process (e.g. Al Ghamdi, 2005; Dincer, Tatoglu \& Glaister, 2006; Aldehayyat \& Anchor, 2008; Al-Shammari \& Hussein, 2008; Elbanna, 2010). However, the research of tourism organisations is outside the scope of this article. The study carried out by Aldehayyat (2011) is the only one to have reported on strategic planning in Jordanian hotels. Aldehayyat, (2011) studied the practice of strategic planning in Jordanian hotels in two cities: Petra and Aqaba. This research indicated that Jordanian hotels have engaged with the strategic planning process by using a number of its techniques, and that the nature of this engagement is affected by organisational size but not by type of ownership. The small sample of the previous study made the ratio between the number of items in the instrument and in the observation 1:1; this could affect the generalisability of the findings. Aldehayyat's (2011) study recommended that future research should include other regions in Jordan and consider the effect of the star rating classification on strategic planning practices. This research furthermore strongly emphasised that the relationship between strategic planning and hotel effectiveness is an area for further research.

On the international level, Athiyaman and Robertson (1995) studied strategic planning in Australian tourism and manufacturing organisations. The aim of their study was to report whether or not tourism organisations lagged behind manufacturing organisations in the use of strategic planning. Four dimensions of strategic planning were highlighted: attention to internal aspects, attention to external aspects, use of techniques, and functional 
integration. They found that there are no statistically significant differences between tourism and manufacturing organisations in relation to the four dimensions of strategic planning. Phillips and Moutinho (1999), on the other hand, conducted a study within the UK hotel sector that aimed to discover the relationships between strategic planning and business performance. The study identified four dimensions from the related literature to study the strategic planning process: formalisation, participation, sophistication and thoroughness. Phillips \& Moutinho (1999) found many statistically significant relationships between strategic planning dimensions and business performance.

The current research, therefore, aims to provide new empirical evidence about strategic planning characteristics in Jordanian hotels, and to examine their relationship with organisational effectiveness. More specifically, the objectives of this research are fivefold: 1) to investigate the strategic planning characteristics in Jordanian hotels; 2) to examine the relationship between these characteristics and organisational effectiveness; 3 ) to explore the organisational characteristics (hotel location, star rating) that influence the practice of strategic planning; 4) to summarize the findings and state the conclusions of the research and its objectives in terms of their contribution to existing literature and their implications for hotel managers and decision makers in the tourism sector in order to enhance their competitiveness; 5) to compare, where possible, the practice of strategic planning by Jordanian hotels with those practices reported in other types of industries in different contexts.

\subsection{Strategic Planning Characteristics}

Most previous studies on strategic planning have employed a single approach, such as the presence or absence of planning, its degree of formality or the length of the planning horizon. As shown in Table 3, the empirical research in different industry contexts - including that of hospitality - and in different country contexts has emphasized the most common and most important dimensions for studying strategic planning. As a consequence, this research adapts these dimensions to examine strategic planning in Jordanian hotels. The dimensions included are: participation and involvement in strategic planning, the time horizon for planning, environmental scanning (internal and external), planning techniques, and functional coverage.

Table 3. Strategic planning dimension as examined in the literature

\begin{tabular}{|c|c|}
\hline Study & Strategic planning dimension \\
\hline $\begin{array}{l}\text { Ramanujam et al. } \\
\text { (1986) }\end{array}$ & $\begin{array}{l}\text { System capability, use of strategy tools and techniques, attention to internal facets, } \\
\text { attention to external facets, functional coverage, resources provided for planning and } \\
\text { resistance to planning. }\end{array}$ \\
\hline $\begin{array}{l}\text { Athiyaman and } \\
\text { Robertson (1995) }\end{array}$ & $\begin{array}{l}\text { Attention to internal aspects; attention to external aspects; use of techniques; and } \\
\text { functional integration. }\end{array}$ \\
\hline $\begin{array}{l}\text { Karger and Parnell } \\
\text { (1996) }\end{array}$ & $\begin{array}{l}\text { Degree of internal orientation, degree of external orientation, degree of integration } \\
\text { achieved within functional department, extent of key personnel involvement in planning } \\
\text { process, extent of use of analytical techniques in addressing strategic planning issues, } \\
\text { creativity in planning and focus on control. }\end{array}$ \\
\hline $\begin{array}{l}\text { Boyd and } \\
\text { Reuning-Elliott } \\
\text { (1998) }\end{array}$ & $\begin{array}{l}\text { Mission statement, trend analysis, competitor analysis, long term goals, annual goals, } \\
\text { short-term action plans and ongoing evaluation. This research is conducted in two } \\
\text { independent samples in the US. }\end{array}$ \\
\hline $\begin{array}{l}\text { Yasai-Ardekania and } \\
\text { Haug (1997) }\end{array}$ & $\begin{array}{l}\text { Process formality, size of planning effort, process sophistication, planning horizon, and } \\
\text { the extent of the involvement of the CEO and top management and line management in } \\
\text { the planning process. }\end{array}$ \\
\hline $\begin{array}{l}\text { Phillips and } \\
\text { Moutinho (1999) }\end{array}$ & Formalisation, participation, sophistication and thoroughness. \\
\hline $\begin{array}{l}\text { Koufopoulos et al. } \\
\quad \text { (2005) }\end{array}$ & $\begin{array}{l}\text { Planning formality and completeness, internal and external orientation, CEO's } \\
\text { involvement, centralisation of the process, time horizon of planning and the frequency }\end{array}$ \\
\hline $\begin{array}{c}\text { Elbanna } \\
(2010)\end{array}$ & $\begin{array}{l}\text { Involvement in planning activities, written strategic plans, time horizon for planning and } \\
\text { strategy techniques }\end{array}$ \\
\hline $\begin{array}{l}\text { Efendioglu and } \\
\text { Karabulut (2010) }\end{array}$ & chniques, strategic planning issues and planning process. \\
\hline
\end{tabular}




\subsection{Organisational Effectiveness}

Organisational effectiveness is the concept of how an organisation is in achieving the it intends to produce. Effective organisations, as defined by Mott (1972), are "those that produce more and higher quality outputs and adapt more effectively to environmental and internal problems than do other similar organizations". Richard, Devinney, Yip \& Johnson (2009) have added that organisational effectiveness captures organisational performance plus the myriad internal performance outcomes normally associated with more efficient or effective operations and other external measures that relate to considerations which are broader than those simply associated with economic valuation by shareholders, managers, or customers.

The literature on the relationship between strategic planning and organisational effectiveness falls into two main categories. Griggs (2002) stated that the first category relates planning to improved profitability, while the second recognizes that good planning is a key to success. The prescriptive strategic management literature (e.g. Glaister \& Falshaw, 1999; Aldehayyat, 2011) advocates the positive relationship between strategic planning and organisational effectiveness. In their meta-analysis, Schwenk \& Schrader (1993) reviewed 26 articles researching businesses organisations and found a positive relationship between strategic planning and organisational performance. Greenley (1994) reviewed 29 pieces of research and found evidence supporting a relationship between strategic planning and organisational effectiveness. Miller \& Cardinal (1994) reviewed 26 published items of research and also found that strategic planning positively affected organisation effectiveness.

More recently, Kraus, Harms, \& Schwarz (2006) found that planning formalisation has a positive effect on organisational performance in Austrian organisations. In Nigerian banks, Taiwo \& Idunnu (2007) found that strategic planning enhances better organisational performance. Within the context of Turkish manufacturing organisations, Glaister et al. (2008) found a significant positive relationship between formal planning process and organisational performance. Like their Turkish counterparts, Egyptian organisations have been found to believe that strategic planning practice is positively related to strategic planning effectiveness (Elbanna, 2008).

Orbit (2008) classified hotel star rating as follows. Five stars are given to luxury hotels, which treat customers very well, with first-class service and accommodations. These hotels' restaurants are often renowned for their famous chefs and delectable dishes. Other amenities include valet parking, concierge service, room service, well-equipped fitness centres and state-of-the-art business centres. Four-star hotels are deluxe and offer comfort, class and quality. These hotels will usually be in a prime location and other amenities may include proximity to desirable shopping areas and restaurants, valet parking, concierge service, room service, well-equipped fitness centres and state-of-the-art business centres. Pinea \& Phillips (2005) studied the influence of star rating on performance in Chinese hotels and found that overall the higher the star rating, the better the performance.

Hotel location, according to Zailani, Fernando \& Mohamed (2011), is a strategic issue that attracts and influences customers to choose a certain hotel. The best location offers exceptional views of or proximity to the city, beach, airport or hillsides. Normally, where hotels are located in the city, people are staying there to enjoy the city's ancient buildings and its shopping malls and streets. Nevertheless, where hotels are located on beach, people are staying there to enjoy the sand sunrise and sunset.

\section{Research Methodology}

To satisfy the aim of this article - researching strategic planning and organisational effectiveness in Jordanian hotels - a positivistic methodology is adopted. This adoption, as justified by Oppenheim (2000), is required when there is a need for both quantitative data and a large sample to carry out the data analysis.

\subsection{Research Population and Respondents}

The population of this research is defined as all hotels in Jordan classified with four and five stars. The names and addresses of the targeted hotels were drawn from the Ministry of Tourism and Antiquities. A total of 46 hotels are studied and data were obtained via self-administrated questionnaires. Since managers, as suggested by Bart et al. (2001) and Aldehayyat \& Anchor (2008), are the most capable persons to provide a valid response to questions related to the hotels' strategies, three managers from each hotel are considered as the research target respondents. Such multiple respondents, moreover, will enable the researcher to obtain a clear picture of the situation in the hotels.

\subsection{Data Collection Method}

This research adopts a survey research design in order to collect a large amount of data from a large sample in a short time and in an economical way. A questionnaire is therefore used to collect primary data. This method was used by much of the previous research in similar areas (e.g. Ghobadian et al., 2008; Elbanna, 2010; Aldehayyat, 2011). 


\subsection{Measurement}

The questionnaire consists of two main parts. which include 64 items. The first part of questions is grouped into five sets of questions related to strategic planning dimensions. The first set is designed to examine the degree of participation by the person/group involved in the strategic planning process. Respondents are asked to indicate the extent of their participation in the strategic planning process on a five-point scale ranging from "not participating at all" to "strongly participating". The second set of questions is designed to examine the time horizon of planning. Respondents are asked to indicate the time horizon for planning in their hotels. The third set of questions involves attention to internal and external aspects. Respondents are asked to indicate the degree of emphasis placed on each of the nine environmental scanning variables (internal and external areas) on a five-point scale, ranging from "significantly less emphasis" to "significantly more emphasis". The scale was adapted from Ramanujam, Venkatraman \& Camillus (1986) and Ramanujam \& Venkatraman (1987). The fourth set of questions involves the use of strategy techniques. In this set, respondents are asked to indicate the extent of the use of strategy techniques in their strategic planning on a five-point scale, rating from "not used at all" to "very great use". The last set of questions relates to functional coverage. Respondents are asked to indicate the degree of emphasis placed on each of the seven functional areas, as suggested by Ramanujam et al. (1986) and Ramanujam and Venkatraman (1987), on a five-point scale ranging from "significantly less emphasis" to "significantly more emphasis".

The second parts of the questions are grouped into four sets and designed to measure organisational effectiveness. These sets, as shown in Table 4, are derived from the related previous literature and include satisfaction and life interest, profitability, work effectiveness and fulfilment of hotel objectives. A five-point scale, as suggested by Griggs (2002), is used to measure organisational effectiveness. The questionnaire also includes questions related to location and star rating of each hotel (four stars or five stars) and participants' age, gender, position, work experience in current position and total work experience.

Table 4. Supported literature for measurement strategic planning

\begin{tabular}{ll}
\hline \multicolumn{1}{c}{ Dimensions } & \multicolumn{1}{c}{ Description } \\
\hline Attention to & $\begin{array}{l}\text { The degree of attention given to past } \\
\text { performance and analysis of strength } \\
\text { and weakness }\end{array}$
\end{tabular}

$\begin{array}{ll}\begin{array}{l}\text { Attention to } \\ \text { external } \\ \text { aspects }\end{array} & \begin{array}{l}\text { The attention given to monitoring } \\ \text { environmental trends }\end{array} \\ \text { Use of } & \begin{array}{l}\text { The degree of attention paced on } \\ \text { strategic technique to structure }\end{array} \\ \text { ill-defined strategic problems }\end{array}$

Involvement of The degree of involvement of top and key personnel line management in strategic planning process

The extent of covearge given to different functional areas with a view

Functional coverage

Time horizon to integrating different functional requirement into a general management perspective

\section{Support literatures}

Ramanujam et al. (1986); Karger and Parnell (1996); Koufopoulos et al. (2005); Aldehayyat (2011); Athiyaman and Robertson (1995); Oreja-Rodrrguezand Yanes-Estévez (2007).

Ramanujam and Venkatraman (1987); Karger and Parnell (1996); Koufopoulos et al. (2005); Aldehayyat (2011); Oreja-Rodrrguez and Yanes-Estévez (2007)

Elbanna (2010), Aldehayyat (2011); Efendioglu and Karabulut (2010); Aldehayyat and Anchor, (2008); Phillips and Moutinho (1999); Boyd and Reuning-Elliott (1998); Stonehouse and Pemberton, J. (2002); Dincer, et al. (2006).

Kaissi et al. (2008); Elbanna (2010); Yasai-Ardekania and Haug (1997); Koufopoulos et al. (2005); Oswald et al. (1994); Ugboro (1991); Wooldridge and Floyd (1990).

McLarney (2003); Athiyaman and Robertson (1995); Aldehayyat (2011); Ramanujam et al. (1986); Glaister. and Falshaw (1999); Phillips and Moutinho (1999)

Elbanna (2010); Yasai-Ardekania and Haug (1997); Koufopoulos et al. (2005); Larsen et al. (2000); Houlden (1996). 


\subsection{Reliability and Validity of the Research Instrument}

A reliability test is carried out using Cronbach's alpha, which measures the internal consistency of a construct. As shown in Table 5, the values of all constructs exceeded the $60 \%$ level. These values are acceptable, according to Hair et al. (2003) and Sekaran (2003), and thus the constructs passed the reliability test.

Table 5. Values of Cronbach's alpha for the research constructs

\begin{tabular}{cc}
\hline Construct & Value \\
\hline Involvement in strategic planning & 0.864 \\
Environment scanning & 0.803 \\
Time horizon & 0.724 \\
Functional converge & 0.870 \\
Use of strategy tools & 0.750 \\
Satisfaction and life interest & 0.830 \\
Work effectiveness & 0.813 \\
Profitability & 0.735 \\
Fulfillment of objectives & 0.720 \\
\hline
\end{tabular}

Having defined the research variables and developed the scaling technique, there is a need to be sure that the instrument used measures the variables it is supposed to, and measures them accurately (Sekaran, 2003, p. 203). To achieve validity, a number of procedures are followed. Such procedures, as suggested by Remenyi et al., (1997), include: a) reviewing a large body of literature to carefully identify concepts, ideas, relationships and issues under study; b) developing the questionnaire from existing related studies; and c) pre-testing the questionnaire formally with executive and academic experts to evaluate whether individual items appear to be appropriate measures of their respective constructs. All suggestions and comments regarding structure, wording and questions were considered in the final draft of the questionnaire.

\subsection{Administering the Questionnaire and Response Rate}

A total of 138 questionnaires were personally handed to a population of 46 hotels, in which three questionnaires have benn receied by each hotel. To increase the response rate, as recommended by Oppenheim (2000), a number of procedures were taken. These procedures included: a) conducting a pilot study, b) delivering and collecting questionnaires by hand, c) assuring respondents that the survey information will be treated as confidential; d) offering reminders to respondents who are late in returning the questionnaire.

Out of 138 questionnaires, 111 valid responses were received. The response rate was $80.4 \%$. This rate, as argued by Saunders et al., (2009), is high compared with the other studies in the same area.

\subsection{Profile of Respondents}

The findings show that: a) $55 \%$ of respondents are under the age of 40 years versus $45 \%$ above the age of 41 ; b) $81.1 \%$ of respondents were male and $18.9 \%$ female; c) $48.6 \%$ of the respondents held bachelor degrees while $51.4 \%$ were postgraduates, and $41 \%$ of respondents had total work experience of less than ten years; d) $47.7 \%$ of respondents were from five-star hotels and $52.3 \%$ from four-star hotels; e) $42.3 \%$ of respondents were from hotels in the city of Amman, 22.5\% were from hotels in the city of Aqaba, 20.7\% were from hotels in the city of Petra and $14.5 \%$ were from hotels in the Dead Sea area. 


\section{Findings and Discussion}

\subsection{Time Horizon for Planning}

Statistical analysis shows that the mean time horizon for strategic planning for these hotels is 5.4 years. Surprisingly, this finding is inconsistent with a previous study by Aldehayyat (2011) undertaken in the Jordanian context, which found that the time horizon for hotels in two cities in Jordan - namely, Petra and Aqaba - is 3.1 years. The finding is also inconsistent with a previous study by Stonehouse and Pemberton (2002) who found that the median value for the planning horizon in UK organisations is 3 years. The findings of this research, however, are consistent with Dincer et al.'s (2006) study in the context of Turkish organisations, which found that very few organisations had a planning horizon of more than 4 years.

As shown in Table 6, a Pearson correlation test indicates a negative relationship between the star classification of the hotel and the time horizon for strategic planning $(r=-.190, p<.01)$. As determined by one-way ANOVA $(F=3.161, \mathrm{p}=.028)$, there is a statistically significant difference between hotel location and time horizon. Multiple Comparisons Dependent Variable (Scheffe) indicates that hotels in Petra have longer time horizons than hotels in Aqaba.

Table 6. Correlations between strategic planning dimensions and hotel-specific characteristics

\begin{tabular}{lcc}
\hline \multicolumn{1}{c}{ Strategic planning dimensions } & $\begin{array}{c}\text { Star rating } \\
\text { Pearson }(2 \text {-tailed }) \mathrm{r}(p)\end{array}$ & $\begin{array}{c}\text { Location } \\
\text { ANOVA-Test } \mathrm{F}(p)\end{array}$ \\
\hline $\begin{array}{l}\text { Time horizon for planning } \\
\text { Participation and involvement in strategic } \\
\text { planning }\end{array}$ & $-.190 ;(.046)$ & $3.161 ;(.028)$ \\
Environmental scanning & $-.122 ;(.201)$ & $.928 ;(0.153)$ \\
Strategy tools & $.222 ;(.019)$ & $.472 ;(.702)$ \\
Functional coverage & $-.057,(.554)$ & $.323 ;(.808)$ \\
\hline
\end{tabular}

As shown in Table 7, a Pearson correlation test furthermore indicates a negative relationship between the time horizon for strategic planning and objectives fulfilment $(r=-.336, p<.01)$. The finding suggests that the longer the time horizon in these hotels, the more negative consequences are found for objectives fulfilment, and therefore less organisational effectiveness is found.

Table 7. The correlation between time horizon and organizational effectiveness

\begin{tabular}{clccccc}
\hline & Time horizon & $\begin{array}{c}\text { Satisfaction } \\
\text { life }\end{array}$ & Profitability & $\begin{array}{c}\text { Work } \\
\text { Effectiveness }\end{array}$ & $\begin{array}{c}\text { Objectives } \\
\text { Fulfillment }\end{array}$ \\
\hline \multirow{2}{*}{ Time horizon } & Pearson & 1 & .099 & -.085 & .100 & $-.336^{* *}$ \\
& Sig. (2-tailed) & & .301 & .375 & .296 & .000 \\
& $\mathrm{~N}$ & 111 & 111 & 111 & 111 & 111 \\
\hline
\end{tabular}

Note: ** Correlation is significant at the 0.01 level (2-tailed)

One possible explanation for these findings relates to political instability. While Jordan is considered a stable country, it is located at the heart of a politically volatile region: the Middle East. Tourism in Jordan, thus, is strongly correlated with tourism in neighbouring countries, and long-time horizons for planning are therefore not suitable for these hotels. 


\subsection{Participation and Involvement in Strategic Planning}

Statistical analysis shows that participation and involvement in the strategic planning process is mostly undertaken by outside consultants (mean 4.275). General managers, planning departments and boards of directors have less involvement in the process (mean 3.927, mean 3.810, mean 3.300) respectively. As shown in Tables 6 and 8, there is no significant correlation between star rating classification and participation and involvement in strategic planning. As determined by one-way ANOVA, there is no statistically significant difference between hotel location in participation and involvement in strategic planning.

Table 8. The correlation between participation in strategic planning process and organisational effectiveness

\begin{tabular}{|c|c|c|c|c|c|c|}
\hline & & Participation & $\begin{array}{c}\text { Satisfaction } \\
\text { Life } \\
\end{array}$ & Profitability & $\begin{array}{c}\text { Work } \\
\text { Effectiveness }\end{array}$ & $\begin{array}{l}\text { Objectives } \\
\text { Fulfillment }\end{array}$ \\
\hline \multirow{3}{*}{ Participation } & Pearson & 1 & .000 & .031 & .031 & .051 \\
\hline & Sig. (2-tailed) & & .996 & .747 & .746 & .595 \\
\hline & $\mathrm{N}$ & 111 & 111 & 111 & 111 & 111 \\
\hline
\end{tabular}

The majority of responding hotels believe that the strongest participation and involvement in planning is undertaken by outside consultants. This belief indicates that hotels recognise the potential value of involving outside resources (e.g. consultants, bankers, accountants, etc.) in the development of their strategic plans. This finding, however, is inconsistent with Elbanna's (2010) finding that in UAE organisations, CEOs, managing directors and boards of directors have the strongest participation and involvement in planning. Similarly, Slavik (2010) found that the greatest participation in strategic planning within Slovakian organisations is undertaken by top management. Like their Slovakian counterparts, Turkish and Egyptian organisations' (Dincer et al., 2006; Elbanna, 2007) general managers have the highest level of involvement; line managers and outsiders participate far less. Thus, des[pite that the empirical research emphasise the importance of top and line management in strategic planning process (e.g. Savaneviciene \& Stankkeviciute, 2011), the Jordanian findings suggest that Jordanian hotels give less attention to participation of line and top management.

\subsection{Environmental Scanning}

Statistical analysis shows that all issues related to environmental scanning are above mean 3. The most significant issues regarding environmental scanning are technological trends (mean 4.009), worldwide competitive trends (mean 3.594), supplier trends (mean 3.407), reasons for past failures (mean 3.414) and regulatory issues (mean 3.369). In line with previous research (e.g. Koufopoulos, Logoudis \& Pastra, 2005; Dincer et al., 2006; Aldehayyat, 2011), Jordanian hotels use internal scanning less than external scanning. This use is explained by Aldehayyat (2011) who argued that Jordan is facing uncertainty, especially in its external environment, and thus external scanning is needed more than internal scanning. Al Khattab et al. (2008) added that Jordanian organisations have shown great interest in assessing political trends, and most organisations have assessed political risk at some time. Thus, Jordanian hotels satisfy the scanning requirements in order to be attentive to the opportunities and challenges that may arise due to the high levels of changes occurring in these areas (Jogaratnam \& Law, 2006).

As shown in Table 6, the result of a Pearson correlation test indicates a significant relationship between star rating classification and environment scanning $(r=.222, p<.05)$. The lower a hotel's star rating, the less it is able to both adopt sophisticated strategic planning practices and undertake comprehensive screening of its external environment. The one-way ANOVA, on the other hand, suggests that there is no statistically significant difference with regard to hotel location and undertaking environmental scanning. Regarding environmental scanning and organizational effectiveness, as shown in Table 9 , the correlation test indicates a significant relationship between environmental scanning and objectives fulfilment $(r=.207, p<.05)$. Olsen et al. (1994) explained such a correlation by stating that scanning of the environment leads to improved performance. Harrington (2004), in his study of US food service organisations, confirms this finding, stating that the fit between environmental and strategic process contingencies leads to improved performance. 
Table 9. The correlation between environmental scanning and strategic planning process and organisational effectiveness

\begin{tabular}{clccccc}
\hline & & $\begin{array}{c}\text { Environmental } \\
\text { Scanning }\end{array}$ & $\begin{array}{c}\text { satisfaction } \\
\text { Life }\end{array}$ & Profitability & $\begin{array}{c}\text { Work } \\
\text { Effectiveness }\end{array}$ & $\begin{array}{c}\text { Objectives } \\
\text { Fulfillment }\end{array}$ \\
\hline \multirow{2}{*}{$\begin{array}{c}\text { Environmental } \\
\text { Scanning }\end{array}$} & Pearson & 1 & .051 & .166 & -.010 & $.207^{*}$ \\
& Sig. (2-tailed) & & .598 & .082 & .918 & .029 \\
& $\mathrm{~N}$ & 111 & 111 & 111 & 111 & 111 \\
\hline
\end{tabular}

Note: $*$ Correlation is significant at the 0.05 level (2-tailed)

\subsection{Strategy Techniques}

The strategic planning tools and techniques most commonly used by Jordanian hotels are human resource analysis (mean 4.324), SWOT analysis (mean 4.225) and financial analysis of competitors (mean 4.054). Like UAE organisations (Elhanan, 2010), Jordanian hotels balance external and internal factors in the strategic planning process: human resource analysis analyses the internal environment, while financial analysis for competitors analyses the external environment. SWOT analysis, on the other hand, connects the two. The strategic planning tools and techniques least commonly used by Jordanian hotels, meanwhile, are scenario construction (mean 3.00), PEST analysis (mean 3.081) and analysis of key (critical) success factors (mean 3.099).

Nevertheless, as shown in Table 6, there is no significant relationship between the star rating classification of hotels and the use of strategy tools. There is also no statistically significant difference between hotel location and the use of strategy tools. As shown in Table 10, the correlation test indicates a positive relationship between the use of strategy tools and objectives fulfilment $(r=.379, p<.01)$. Like their UK counterparts (Phillips \& Moutinho, 1999), Jordanian hotels believe that using strategic planning tools and techniques can increase their effectiveness.

Table 10. The correlation between strategy tools and organisational effectiveness

\begin{tabular}{ccccccc}
\hline & & $\begin{array}{c}\text { Strategy } \\
\text { Tools }\end{array}$ & $\begin{array}{c}\text { Satisfaction } \\
\text { Life }\end{array}$ & Profitability & $\begin{array}{c}\text { Work } \\
\text { Effectiveness }\end{array}$ & $\begin{array}{c}\text { Objectives } \\
\text { Fulfillment }\end{array}$ \\
\hline \multirow{3}{*}{ Strategy Tools } & Pearson & 1 & .096 & .070 & .086 & $.379^{* *}$ \\
& Sig. (2-tailed) & & .315 & .467 & .368 & .000 \\
& $\mathrm{~N}$ & 111 & 111 & 111 & 111 & 111 \\
\hline
\end{tabular}

Note: $* *$ Correlation is significant at the 0.01 level (2-tailed)

\subsection{Functional Coverage}

Regarding the functional coverage of strategic planning, the higher mean scores are for operations/manufacturing functions (mean 3.844), followed by worldwide competitive trends (mean 3.614), then finance functions (mean 3.321). The lowest mean scores are for purchasing (mean 2.912) and research and development and technology (mean 2.234). The strategic planning within Jordanian hotels covers most of these functions (mean 3 and above). The lack of interest in the most important function - namely, research and development and technology - suggests that Jordanian hotels depend on foreign research and technology. Aldehayyat \& Twaissi (2011) confirmed this notion, finding that the average spend on research and development in developing countries is far less than those in developed countries.

As shown in Table 6, there is no significant relationship between the star rating of the hotel and functional coverage. There is also no statistically significant difference between hotel location and functional coverage. Table 11, on the other hand, indicates a positive relationship between functional coverage and profitability $(r=.380, p<.01)$. Like their UK counterparts (Phillips \& Moutinho, 1999), Jordanian hotels believe functional coverage is critical to the effectiveness of strategic planning in hotels. 
Table 11. The correlation between functional coverage and organisational effectiveness

\begin{tabular}{clccccc}
\hline & & $\begin{array}{c}\text { Functional } \\
\text { Converge }\end{array}$ & $\begin{array}{c}\text { Satisfaction } \\
\text { Life }\end{array}$ & Profitability & $\begin{array}{c}\text { Work } \\
\text { Effectiveness }\end{array}$ & $\begin{array}{c}\text { Objectives } \\
\text { Fulfillment }\end{array}$ \\
\hline \multirow{3}{*}{$\begin{array}{c}\text { Functional } \\
\text { Coverage }\end{array}$} & Pearson & 1 & .152 & $.380^{* *}$ & .070 & .168 \\
& Sig. (2-tailed) & & .112 & .000 & .466 & .078 \\
& $\mathrm{~N}$ & 111 & 111 & 111 & 111 & 111 \\
\hline
\end{tabular}

Note: $* *$ Correlation is significant at the 0.01 level (2-tailed)

\subsection{Strategic Planning and Organizational Effectiveness in Jordanian Hotels}

As shown in Table 12, there is a positive relationship between strategic planning and organizational effectiveness $(r=.226, p<.05)$. Like their Australian (Kraus et al., 2006), Nigerian (Taiwo \& Idunnu, 2007), Turkish (Glaister et al., 2008) and UAE counterparts (Elbanna, 2008), Jordanian hotels realise the value of strategic planning to organisational effectiveness.

Table 12. The correlation between overall strategic planning and organisational effectiveness

\begin{tabular}{clcc}
\hline & & Strategic planning & $\begin{array}{c}\text { Organizational } \\
\text { Effectiveness }\end{array}$ \\
\hline \multirow{2}{*}{ Strategic planning } & Pearson & 1 & $.226^{*}$ \\
& Sig. (2-tailed) & & .017 \\
& $\mathrm{~N}$ & 111 & 111 \\
Organizational & Pearson & $.226^{*}$ & 1 \\
Effectiveness & Sig. (2-tailed) & .017 & \\
& $\mathrm{~N}$ & 111 & 111 \\
\hline
\end{tabular}

Note: * Correlation is significant at the 0.05 level (2-tailed)

\section{Conclusions and Implications}

This research offers some important insights into strategic planning and organisational effectiveness in the hotel industry. In particular, it conceptualises and measures organisational effectiveness in hotels within the context of an emerging-market country. This research, furthermore, is one of the first attempts to empirically examine organisational effectiveness in Jordan, which is located in the heart of a politically and economically volatile region, the Middle East. This is crucial in order to understand the behaviour of hotels in the region. The research, moreover, fills some of the major theoretical gaps in the previous literature. While most previous studies on strategic planning have employed a single approach, such as the presence or absence of planning, its degree of formality or the length of the planning horizon, this research considers many dimensions to examine strategic planning in Jordanian hotels, including participation and involvement in strategic planning, the time horizon for planning, environmental scanning (internal and external), planning techniques and functional coverage.

The findings of this research have revealed several important implications for management and managerial practitioners in the Jordanian hotel industry. First, due to the changing environment, managers should consider planning over a shorter time horizon than the present 5.4 years, as the long time spent on planning is found to be negatively related to organisational effectiveness. Second, due to their important roles, top management and boards of directors need to be more involved in the strategic planning process. Third, it is important, therefore, that scanning should include a focus on internal strategic factors as well. Fourth, managers should pay more attention to important strategy analysis tools such as analysis of organisational culture and scenario construction. The use of these tools is believed to be useful for hotels' activities in a high-uncertainty environment. Fifth, strategic plans ought to cover all functional areas, especially research and development and technology. 
In line with the business literature, a multidimensional approach to strategic planning should be practiced in order to see its full benefits, which include organisational effectiveness. The research provides an insight into the relationship between the practice of strategic planning and certain organisational characteristics (star rating and location); the implementation of strategic planning in hotels could be an area for further research.

\section{Acknowledgement}

The authors acknowledge the financial support of Scientific Research Fund (SRF), Ministry of Higher Education \& Scientific Research, Amman, Jordan in carrying out this research.

\section{References}

ABC Investments. (2009). Tourism Sector Report (2009). Retrieved on 3 May 2012 from http://www.abci.com.jo/cms_files/Financial_Statement_31-12-2009.pdf

Al Ghamdi, S. (2005). The use of strategic planning tools and techniques in Saudi Arabia: an empirical study. International Journal of Management, 22(3), 376-395.

Aldehayyat, J., \& Twaissi, N. (2011). Strategic planning and corporate performance relationship in small business firms: evidence from a Middle East country context. International Journal of Business and Management, 6(8), 255-263. http://dx.doi.org/10.5539/ijbm.v6n8p255

Aldehayyat, J. (2011). Organizational characteristics and the practice of strategic planning in Jordanian hotels. $\begin{array}{llll}\text { International Journal of Hospitality } & \text { Management, 30(1), }\end{array}$ http://dx.doi.org/10.1016/j.ijhm.2010.05.001

Aldehayyat, J., \& Anchor, J. (2008). Strategic planning tools and techniques in Jordan: awareness and use. Strategic Change, 17(7/8), 281-293. http://dx.doi.org/10.1002/jsc.833

AlKhattab, A., Anchor, J., \& Davies, A. (2008). The institutionalisation of political risk assessment (IPRA) in Jordanian international firms. International Business Review, 17(6), 688-702. http://dx.doi.org/10.1016/j.ibusrev.2008.09.007

Al-Shammari, H., \& Hussein, R. (2008). Strategic planning in emergent market organisations: empirical investigation. International Journal of Commerce and Management, 18(1), 47-59. http://dx.doi.org/10.1108/10569210810871489

Ardahaey, F. (2011). Economic impact of tourism industry. International Journal of Business and Management, 7(8), 206-215. http://dx.doi.org/10.5539/ijbm.v6n8p206

Athiyaman, A., \& Robertson, R. (1995). Strategic planning in large tourism firms: an empirical analysis. Tourism Management, 16(3), 199-205. http://dx.doi.org/10.1002/(SICI)1097-0266(199802)

Bart, C., Bontis, N., \& Taggar, S. (2001). A model of the impact of mission statements on firm performance. Management Decision, 39(1), 19-35. http://dx.doi.org/10.1108/EUM0000000005404

Boyd, B., \& Reuning-Elliott, E. (1998). Research note and communications: a measurement model of strategic planning. Strategic Management Journal, 19(2), 181-192. http://dx.doi.org/10.1002/ (SICI) 1097-0266

Brews, P., \& Purohit, D. (2007). Strategic planning in unstable environments. Long Range Planning, 40, 64-80. http://dx.doi.org/10.1016/j.lrp.2006.12.001

Chon, K., \& Olsen, D. (1990). Applying the strategic management process in the management of tourism. Tourism Management, 11(3), 206-213. http://dx.doi.org/10.1016/0261-5177(90)90043-9

Dincer, O., Tatoglu, E., \& Glaister, K. (2006). The strategic planning process: evidence from Turkish firms. Management Research News, 29(4), 206-219. http://dx.doi.org/10.1108/1409170610665068

Elbanna, S. (2007). The nature and practice of strategic planning in Egypt. Strategic Change, 16(5), 227-243. http://dx.doi.org/10.1002/jsc.797

Elbanna, S. (2008). Planning and participation as determinants of strategic planning effectiveness evidence from the Arabic context. Management Decision, 46(5), 779-796. http://dx.doi.org/10.1108/00251740810873761

Elbanna, S. (2010). Strategic planning in the United Arab Emirates. International Journal of Commerce and Management, 20(1), 26-40. http://dx.doi.org/10.1108/10569211011025934

Ghobadian, A., O’Regan, N., Thomas, H., \& Liu, J. (2008). Formal strategic planning, operating environment, size, sector and performance Evidence from the UK's manufacturing SMEs. Journal of General Management, 34(20), 1-20. 
Glaister, K., \& Falshaw, R. (1999). Strategic planning: still going strong? Long Range Planning, 32(1), 107-116. http://dx.doi.org/10.1016/S0024-6301(98)00131-9

Glaister, K., Dincer, O., Tatoglo, E., Demirbag, M., \& Zaim, S. (2008). A causal analysis of formal strategic planning and firm performance evidence from an emerging country. Management Decision, 46(3), 365-391. http://dx.doi.org/10.1108/00251740810863843

Glaister, K., Dincer, O., Tatoglu, E., \& Demirbag, M. (2009). A comparison of strategic planning practices in companies from the UK and Turkey. Journal of Management Development 28(4), 361-379. http://dx.doi.org/10.1108/02621710910947380

Greenley, G. (1994). Strategic planning and company performance: an appraisal of empirical evidence. Scandinavian Journal of Management, 10(4), 383-396. http://dx.doi.org/10.1016/0956-5221(94)90025-6

Griggs, H. (2002). Strategic planning system chrematistics and organizational effectiveness in Australian small-scale firms. The Irish Journal of Management, 23(1), 23-53.

Hair, J., Babin, B., Money, P., \& Samouel, P. (2003). Essential of business research methods. USA: Wiley.

Harrington, R. (2004). The environment, involvement and performance: implication for the strategic process of food service firms. International Journal of Hospitality Management. 23(4), 317-341. http://dx.doi.org/10.1016/j.ijhm.2003.12.004

Houlden, B. (1996). Understanding Company Strategy ( $2^{\text {nd }}$ ed.). Oxford: Blackwell Business.

Jogaratnam, G., \& Law, R. (2006). Environmental scanning and information source utilization: exploring the behavior of Hong Kong hotel and tourism executives. Journal of Hospitality \& Tourism Researc, 30(2), 170-190. http://dx.doi.org/10.1177/1096348005284488

Kaissi, A., Begun, J., \& Welson, T. (2008). Strategic planning processes and hospital financial performance. Journal of Health Care Management, 53(3), 197-209.

Karger, J., \& Parnell, J. (1996). Strategic planning emphasis and planning satisfaction in small firms: an empirical investigation. Journal of Business Strategy, 13(1), 42-64.

Koufopoulos, D., Logoudis, I., \& Pastra, A. (2005). Planning practices in the Greek ocean shipping industry. European Business Review, 17(2), 151-176. http://dx.doi.org/10.1108/09555340510588020

Kraus, S., Harms, R., \& Schwarz, E. (2006). Strategic planning in smaller enterprises-new empirical findings. Management Research News, 29(6), 334-344. http://dx.doi.org/10.1108/01409170610683851

Larsen, P., Tonge, R., \& Ito, M. (2000). Managing the planning process: a comparative analysis between high-growth medium-sized enterprises and the general business population. Journal of Applied Management Studies, 9(2), 275-282. http://dx.doi.org/10.1080/713674369

Majcher-Teleon, A., \& Ben Slimène, O. (2009). Women and work in Jordan: case study of tourism sector and ICT sectors. Working paper, European Training Foundation.

McLarney, C. (2003). A driving force: an analysis of strategic planning in the Canadian automotive industry. Business Process Management Journal, 9(4), 421-439. http://dx.doi.org/10.1108/14637150310484490

Miller, C., \& Cardinal, L. (1994). Strategic planning and firm performance: a synthesis of two decades of research. Academy of Management Journal, 37(6), 1649-1665.

Ministry of Tourism and Antiques. (2011). Jordan National Tourism Strategy. Ministry of Tourism and Antiques of Jordan (2011). Retrieved on 4 May 2012 from http://www.tourism.jo/ar/portals/0/NTS_2011-2015_English.pdf

Mott, P. E. (1972). The Characteristics of Effective Schools. New York: Harper and Row.

Ocasio, O., \& Joseph, J. (2008). Rise and fall-or transformation? the evolution of strategic planning at the General Electric Company 1940-2006. Long Range Planning, 41, 248-272. http://dx.doi.org/10.1016/j.lrp.2008.02.010

Okumus, F. (2002). Can hospitality researchers contribute to strategic management literature? International Journal of Hospitality Management, 21, 105-110. http://dx.doi.org/10.1016/S0278-4319 (01)00033-0

Olsen, M., Murthy, B., \& Teare, R. (1994). CEO perspectives on scanning the global hotel business environment. International Journal of Contemporary Hospitality Management, 6(4), 3-9. http://dx.doi.org/10.1108/09596119410060865 
Oppenheim, A. N. (2000). Questionnaire design interviewing an attitude measurement ( $2^{\text {nd }}$ ed.). Continuum.

Orbit. (2008). Unscramble the star rating system. Retrieved on 10 Feb 2012 from http://www.orbitz .com/pagedef/content/hotel/popupStarRatingGuide.jsp

Oreja-Rodrrguez, J., \& Yanes-Estévez, V. (2007). Perceived environmental uncertainty in tourism: a new approach using the Rasch model. Tourism Management, 28(6), 1450-1463. http://dx.doi.org/10.1016/j.tourman.2006.12.005

Oswald, S., Mossholder, K., \& Harris, S. (1994). Vision salience and strategy involvement: implication for psychological attachment to organisations and job. Strategic Management Journal, 15(6), 477-489. http://dx.doi.org/10.1002/smj.4250150605

Phillips, P., \& Moutinho, L. (1999). Measuring strategic planning effectiveness in hotels. International Journal of Contemporary Hospitality Management, 11(7), 349-358. http://dx.doi.org/10.1108/09596119910293259

Pinea, R., \& Phillips, P. (2005). Performance comparisons of hotels in China. Hospitality Management, 24, 57-73. http://dx.doi.org/10.1016/j.ijhm.2004.04.004

Ramanujam, V., \& Venkatraman, N. (1987). Planning system characteristics and planning effectiveness. Strategic Management Journal, 8(5), 453-468. http://dx.doi.org/10.1002/smj.4250080505

Ramanujam, V., Venkatraman, N., \& Camillus, J. (1986). Multi-objective assessment of effectiveness of strategic planning a discriminate analysis approach. Academy of Management Review, 29(2), 347-372.

Reichel, A. (1983). Strategic management: how to apply it to firms in the hospitality industry. The Service Industries Journal, 3(3), 329-343.

Remenyi, D., Williams, B., Money, A., \& Swartz, E. (1998). Doing research in business and management. London: Sage Publications.

Richard, P., Devinney, T., Yip, G., \& Johnson, G. (2009). Measuring organizational performance: towards methodological best practice. Journal of Management, 35(3), 718-804. http://dx.doi.org/10.1177/0149206308330560

Rigby, D., \& Bilodeau, B. (2007). Bain's global 2007 management tools and trends survey. Strategy and Leadership, 35(5), 9-16. http://dx.doi.org/10.1108/10878570710819161

Rigby, D. (2001). Management tools and techniques: a survey. California Management Review, 43, 139-160. http://www.jstor.org/stable/41166079

Saunders, M., Lewis, P., \& Adrian, T. (2009). Research methods for business students (5th ed.). London: Prentice Hall.

Savaneviciene, A., \& Stankkeviciute, Z. (2010). The interaction between top management and line managers implementing strategic directions into praxis. Inzinerine Ekonomika-Engineering Economics, 22(4), 412-422. http://dx.doi.org/10.5755/j01.ee.22.4.716

Schaffer, J. (1986). Competitive strategy and organizational performance in the lodging industry: an empirical assessment of Miles and Snow's (1987) perspective of organisations. PhD. Thesis. Virginia Polytechnic Institute and State University.

Schwenk, C., \& Schrader, C. (1993). Effects of formal planning on financial performance in small firms: a meta-analysis. Entrepreneurship Theory and Practice, 17(3), 53-63.

Siyaha. (2012). Jordan Tourism Development Project. Retrieved on 25 May 2012 from http://www.siyaha.org/project/overview

Slavik, S. (2010). Process and content analysis of strategic planning in enterprise in Slovakia. Managerial Review, 7(2), 91-81.

Stancious, A., Teodorescu, N., Pargaru, I., Vladol, A., \& Balesc, C. (2011). The image of the tourism destination-a supporting element in the development of the regional tourism Brand study case: Muntenia. Theoretical and Applied Economics, 2(2), 139-152.

Stonehouse, G., \& Pemberton, J. (2002). Strategic planning in SMEs-some empirical findings. Management Decision, 40(9), 853-861. http://dx.doi.org/10.1108/00251740210441072

Taiwo, A., \& Idunnu, F. (2007). Impact of strategic planning on organizational performance survival. Research Journal of Business Management, 1(10), 62-71. http://dx.doi.org/10.3923/rjbm.2007.62.71 
Ugboro, I. (1991). Top management involvement and strategic planning system performance: a validation study. SAM Advanced Management Journal, 56(4), 38-42.

UNWTO. (2009). World Tourism Barometer. World Tourism Organization.

UNWTO. (2010). 2009 an exceptionally challenging year. Tourism Highlights: World Tourism Organization.

Wooldridge, B., \& Floyd, S. (1990). The strategy process, middle management involvement, and organizational performance. Strategic Management Journal, 11(3), 231-241. http://dx.doi.org/10.1002/smj.4250110305

Yasai-Ardekania, M., \& Haug, R. (1997). Contextual determinations of strategic planning process. Journal of Management Studies, 34(5), 729-767. http://dx.doi.org/10.1111/1467-6486.00070

Zailani, S., Fernando, Y., \& Mohamed, A. (2011). Location, star rating and international chain associated with the hoteliers intention for not applying the Halal Logo Certification. European Journal of Social Sciences, 16(3), 401-408. 